Omni-Akuatika Special Issue $3^{\text {rd }}$ Kripik SCiFiMaS 2020: 49 - 60
ISSN: 1858-3873 print / 2476-9347 online
Research Article
journal homepage: http://ojs.omniakuatika.net

\title{
Fishers' resilience towards extreme weather conditions in the South China Sea: A case study of Natuna Islands, Indonesia
}

\author{
Rani Hafsaridewi, Hikmah, Armen Zulham, Permana Ari Soejarwo, Bayu Vita Indah Yanti \\ Research Center Marine and Fisheries Socio-Economic, Ministry of Marine Affairs and Fisheries, 14430 Jakarta, \\ Indonesia \\ *Corresponding author: hafsaridewi@yahoo.com
}

Received 20 November 2019; Accepted 1 October 2020; Available online 31 December 2020

\begin{abstract}
Factors influencing fishers' lives are climate change and extreme change in local weather. Climate change and extreme weather conditions are expected to affect marine fisheries' productivity and modify fish distribution because of changes in water temperature, ocean currents, and other oceanic conditions. Both are issues faced by fishers in Natuna. The purpose of this study was to identify climate and weather changes in the research location, investigate the socio-economic effects, and analyse fishers' adaptability patterns in relation to climate change. The method used in this study includes surveys, questionnaires, in-depth interviews, and focus group discussions. The results reveal climate change, and extreme weather affects the socio-economic dynamics of fishers in the Natuna Islands. The socio-economic dynamics as fishers' resilience towards extreme climate are done by adjusting the number of workers and workforce, adjusting the size of fishing boats/ships, adjusting the composition of fishing gears, and changing fishing grounds.
\end{abstract}

Keywords: Resilience, fishermen, climate change, Natuna, South China Sea

\section{ABSTRAK}

Faktor yang mempengaruhi kehidupan nelayan adalah perubahan iklim dan cuaca daerah yang ekstrim. Perubahan iklim dan kondisi cuaca ekstrim diperkirakan akan mempengaruhi produktivitas perikanan tangkap yang disebabkan oleh perubahan distribusi ikan karena perubahan suhu air, arus laut, dan kondisi laut lainnya. Keduanya merupakan persoalan yang dihadapi nelayan di Natuna. Tujuan dari penelitian ini adalah untuk mengidentifikasi perubahan iklim dan cuaca di lokasi penelitian, mengetahui pengaruh sosial ekonomi, dan menganalisis pola adaptasi nelayan dalam kaitannya dengan perubahan iklim. Metode yang digunakan dalam penelitian ini meliputi survei, kuesioner, wawancara mendalam, dan diskusi kelompok terfokus. Hasil penelitian mengungkap perubahan iklim, dan cuaca ekstrim mempengaruhi dinamika sosial ekonomi nelayan di Kepulauan Natuna. Dinamika sosial ekonomi sebagai ketahanan nelayan terhadap iklim ekstrim dilakukan dengan penyesuaian jumlah tenaga kerja dan tenaga kerja, penyesuaian ukuran perahu / kapal nelayan, penyesuaian komposisi alat tangkap, dan perubahan daerah penangkapan.

Kata Kunci: Ketahanan, nelayan, perubahan iklim, Natuna, Laut Cina Selatan

\section{Introduction}

The concept of resilience was first introduced in the field of Ecology between the $60 \mathrm{~s}$ and $70 \mathrm{~s}$ emerging from studies of population interaction (prey-predator) and functional responses within the Ecological Stability Theory. Holling (1973) illustrated several multiple stability domains or multiple basins of attraction in nature (Holling, 1973). These domains are related to the ecological process, random events (such as disruptions), and heterogeneity based on temporal and spatial scales. Holling then coined the term "resilience" as the ability to persevere in a particular domain during a time of change and suggests that resilience influences the persistence of system interaction and measures the system capability to adjust, direct, and maintain its variables. The term resilience is generally referred to as fast recovery to 
previously good conditions. As a process, resilience is conceptualized as the ability to adapt to environmental changes and to maintain functionality without major changes in its fundamental characteristics (Manyena, 2006). The notion of resilience as adaptability is used in this research. Fishers live in a highly dynamic environment caused by natural or man-made activities, which lead to their vulnerability. Factors that affect fishers' productivity are climate change and extreme weather.

Climate change adversely affects water temperature, ocean currents, and other conditions, which result in the decline of fish productivity and distribution (Cheung et al., 2009). One of the climate change effects is coral bleaching. Coral is a natural feeding ground for several ocean biotas and is also breeding grounds for several types of fish (Wibisono, 2014). Coral damage and death will lead to the decline and migration of fish.

Small-island fishers, such as Natuna, are highly dependent on the surrounding resources. Bad weather and extreme climate change prevent access to fishery resources. Limited accessibility to fishery resources is one factor that cause fisher vulnerability (Hafsaridewi et al., 2019). Fishers in Natuna are facing the abovementioned problems i.e., climate change and extreme weather.

This study also suggests that extreme change in climate and weather in the North Natuna Sea disrupts the socio-economic balance in fishing activities. In responding to the shift, fishers in Natuna adapt their interaction patterns between participants of the economy, so they can still maintain some trading (Yeager, 1999; North, 1990) as well as create business efficiency based on the power structure in the economy, politics, and society (Bardhan , 1989; Challen, 2000). Adaptability of interaction patterns include finding new fishing grounds, altering activities such as changing fishing locations and/or changing their occupations, and restructuring interaction patterns between traders.

In this study, resilience was a way that fishers respond to the effects of climate change and extreme weather. It focuses on the aspect of economy and socio-culture and aims to analyses patterns of fishers adapting to climate change and extreme weather. The purpose of this study was to identify climate and weather changes in the research location, investigate the socio-economic effects, and analyse fishers' adaptability patterns in relation to climate change

\section{Materials and Methods}

This research was located on Natuna Island (Figure 1), Riau Islands Province, Indonesia, and conducted from May through July 2019. Methods used in this study was surveys. The survey method is an investigation that aims to obtain facts from existing symptoms and seek factual information about the social, economic, or political institutions of a group or a region (Nazir, 2003). Data collection through literature study, focus group discussion, indepth interviews, and interviews with questionnaires. Secondary data that has been collected are climate data obtained from BMKG Ranai Station and previous research results, especially on the impact of climate change. Primary data that has been collected are seasonal calendars, fishery activities and their changes, and fisherman adaptation patterns. Collected data both primary and secondary were analysed using a quantitative descriptive approach.

\section{Results and Discussion}

\subsection{Description of Natuna Islands}

Natuna Islands is one of the most prominent islands regions in Indonesia

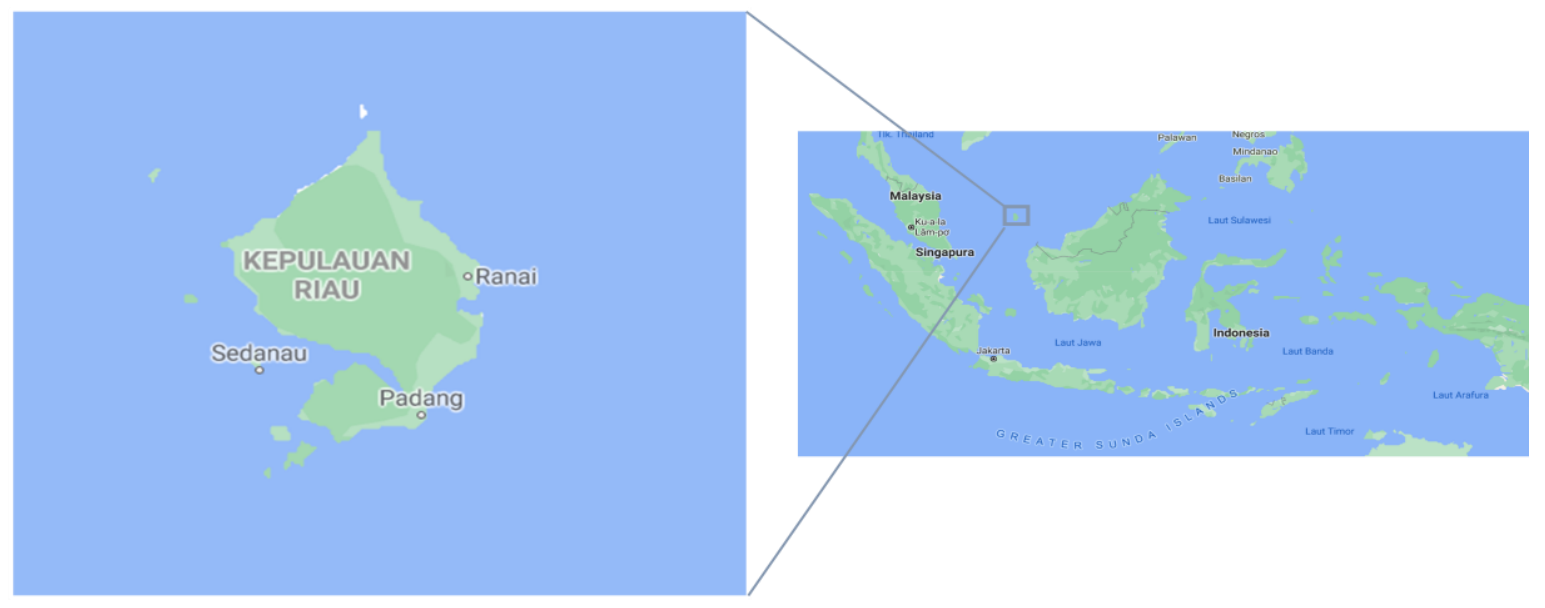

Figure 1. Research Location 
established by the official Law No.53/1999 (Undang-undang No. 53/1999). According to the Law No.33/2008 (Undang-undang No. 33/2008), the total area of Natuna Islands is 264.198,37 $\mathrm{km}^{2}$, with $2.001,30 \mathrm{~km}^{2}$ is area of the land dan $262.197,07 \mathrm{~km}^{2}$ is area of the sea or $99 \%$ of the overall size of Natuna Islands. There are 154 islands, with 27 islands are populated islands $(19,48 \%)$, while others are non-populated. The region is seen as the "terrace" of Indonesia as it shares borders with other counties. In the North, Natuna Islands are adjacent with Vietnam and Cambodia; and in the East, it is adjacent with East Malaysia (Sarawak); in the South, with Bintan island; and in the West, with the Malaysian peninsula.

Fishing activities in Natuna are dominated by small-scale fishing. According to Marine and Fisheries Agency of Natuna Regency, the vessels used by Natuna fishers are dominated by small boats in the size of $1-5$ GT $(60 \%$ or 2398 units), followed by non-motorized boats (23\% or 897 units), vessels in size of $5-10$ GT (10\% or 382 units), vessels with attached motor (6\% or 252 units), and others above 10 GT (1\% or 25 units). Considering that the Natuna seas are a part of the South China Sea, it can be seen that the fishing potentials have not been optimized by the fishers.

Based on the interviews with the official guards of the fishing area, most fishers operate not more than $5^{\circ}$ North latitude (Figure 2) even though the Economy Exclusive Zone of Indonesia covers up to $6^{\circ}$ North latitude. This may be caused by limited vessels and weather conditions in the South China Sea. Before the policy of punishing foreign ships for illegal fishing, many foreign vessels operated between $5^{\circ}-6^{\circ}$ north latitude. The fishers also admit this as they merely received help with fuel from Vietnamese fishers.

\subsection{Climate change and extreme weather in Natuna}

Climatology in the Natuna Islands is affected by global, regional, and local climate. Climate variation in Natuna is also affected by meteorological factors such as wind and topography. Furthermore, climate variation in Natuna is divided into local and regional. The local climate variation is heavily influenced by wind interaction and topography; whereas the regional climate variation is affected by wind circulation from other regions. Based on the regional climate, climate variation in Natuna is also influenced by several phenomena i.e., monsoon, tropical cyclones, the Eddy circulation, and Dipole Mode circulation.

\section{The Asian Monsoon}

Rainy or wet season in Natuna is caused by the wind circulation of the Asian Monsoon or "North Season" according to the locals. The Asian Monsoon is occurred between November - February where the sun is located in the southern hemisphere providing the Australian continent with abundant sunshine, higher temperatures, and lower air pressure (Bayong, 2008).

In contrast, the northern hemisphere which is Asia continent becomes colder and has higher air pressure. As the wind moves from Asia to Australia, it carries evaporated water that turns to rain in most parts of Indonesia including Natuna Islands. In general, the north season causes higher tides that endanger the fishers. Rain is abundant in this active phase, while there is no rain in the passive phase (Hardian, 2015).

In this season, precipitation level increases in Natuna Islands with an annual average of $\pm 1.726 .3 \mathrm{~mm}, 82 \%$ of humidity, and temperature range of $26-27.5^{\circ} \mathrm{C}$. Wind speed may increase to 15-30 knots causing continuous high tides between 1-3 meters. This condition aligns with the field observation that found the north season that characterized with high tides during the night and low tides during the day; increased wind speed; high waves and continuous rain. This weather condition causes difficulties in fishing activities considering that this period of time is a peak season for fishing. As a result, fishers typically have prepared their daily necessities before the monsoon months start. A detailed calendar of the Asian Monsoon is described in Table 1.

\section{Transition Season I}

Transition Season 1 or what Natuna locals referred to as "eastern season" (musim timuran) typically occurs between March until May. This usually causes an increase in fishing results as the weather tend to calm down and the peak
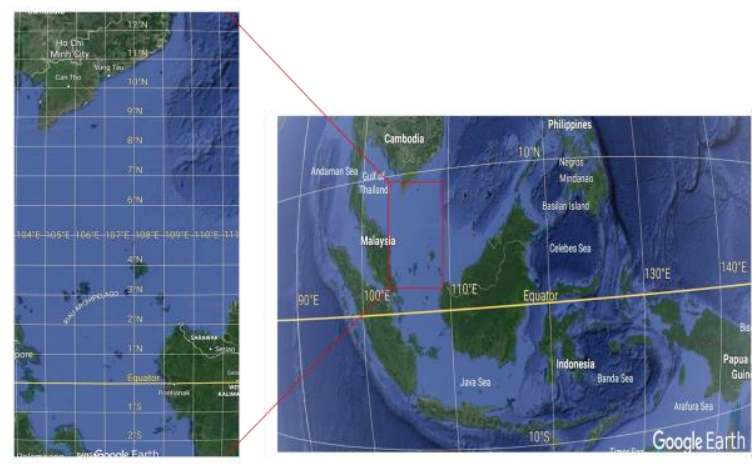

Figure 2. Natuna Fishers' Operational Area 
season of fishing is still continued. In this season, the sun moves to the equator resulting in cooler temperatures and higher air pressure in the Australian continent; whereas the equator region in several Asian areas have higher temperature especially in Indonesia (Aldrian et al., 2011). This season causes a change in wind direction and reduces rain particularly in Natuna. However, orographic rain caused by the local climate is still occurred. A detailed calendar of Transition Season is seen in Table 1.

\section{The Australian Monsoon}

In this season, Natuna Islands has dry season due to the "southern season", which occurs from June to August. A detailed calendar of the Australian monsoon is seen in Table 2. The sun is in the northern hemisphere causing high temperatures and low air pressure in many areas in Asia. In contrast, the Australian continent has low temperatures with higher air pressure compared to Asia continent (Wheleer et al., 2005). As a result, the wind moves from Australia to Asia continent carrying dry wind from the desert and creating a dry season in Natuna. Rain precipitation in the Natuna region during the dry season is $137.6 \mathrm{~mm}$ with an average humidity of $\pm 83.17 \%$. In this season, heavy rain becomes less, the waters receive plenty of sunlight and become warmer. This condition aligns with the field observation which indicates the southern season with characteristics such as low tides in the night and higher tides in the morning, less rain, 3-month dryness, and small ocean waves.

\section{Transition Season II}

Transition Season II or what the locals call "West season" (musim baratan) typically occurred from September to November. In this season, the sun moves to the southern hemisphere causing lower temperatures and higher air pressure in the Asian continent. The equator region, including Indonesia, has lower temperatures, whereas the Australian continent has higher temperatures (Rahayu, 2018). In this season, the wind direction changes and causes alternating rain and heat in Natuna. Calm sea surface can suddenly change to high waves of more than 3 meters, which is dangerous for fishers. A detailed calendar of the Asian monsoon season can be seen in Table 1.

\section{Cyclone Winds}

One factor causing the regional climate in Natuna islands is the tropical cyclone, a wind that enters the center of low temperatures and depression areas surrounded by areas with high pressure, resulting in circulating wind over the boar line (Syaifullah, 2015). Cyclone winds occur in tropical area and often occur in the sea rather than land. It is created from tropical depression or intensively low temperature over the sea causing convection process and cloud formation. The center is a result of the Coriolis movement. In terms of astronomy, Indonesia is not an area that can form tropical cyclones but geographically, it shares borders with areas where tropical cyclones are formed. Cyclone winds have extensive energy, and over the sea surface, this energy can transfer to the ocean stirring deep waters and causing the seabed nutrients to move up to the surface (mixing). This condition helps form fishing grounds. One cyclone occurred in January 2019 where the drunken cyclone wind triggered weather change with wind speed up to 200 knots/hour and caused high tides between 2-7 meters. The drunken cyclone wind increased precipitation in the Northern Sumatra including Natuna, moving from the South China Sea to the coastal area of the east Thailand.

\section{Eddy Circulation}

Another meteorological phenomenon affecting climate variation in Natuna is the Eddy Circulation, a daily circulation pattern in the atmosphere and resembles a wind vortex. The effects of Eddy Circulation is the increase in precipitation and high tides in a particular area. This phenomenon occurred in May 2019 due to weather disruption in the Indian Ocean, north of Aceh, causing convergence and cloud formation in the northern Sumatra.

Table 1. Calendar of the Asian Monsoon, Transition I, the Australian Monsoon, Transition II in Natuna

\begin{tabular}{|c|c|c|c|c|c|c|c|c|c|c|c|c|}
\hline \multirow{2}{*}{ Season } & \multicolumn{12}{|c|}{ Month } \\
\hline & 1 & 2 & 3 & 4 & 5 & 6 & 7 & 8 & 9 & 10 & 11 & 12 \\
\hline Northern Season & $\mathrm{x}$ & $\mathrm{x}$ & & & & & & & & $x$ & $x$ & $x$ \\
\hline Southern season & & & & $x$ & $x$ & $x$ & $x$ & $x$ & & & & \\
\hline Transition Season I & & & $x$ & $x$ & & & & & & & & \\
\hline Transition Season II & & & & & & & & & $x$ & $x$ & & \\
\hline
\end{tabular}

Source: primary data, 2019 
Table 2. Yearly Precipitation (2007-2018) in Natuna

\begin{tabular}{|c|c|c|c|c|c|c|c|c|c|c|c|c|c|}
\hline \multirow{2}{*}{ Month } & \multicolumn{12}{|c|}{ Year } & \multirow{2}{*}{$\begin{array}{l}\text { monthly } \\
\text { average }\end{array}$} \\
\hline & 2007 & 2008 & 2009 & 2010 & 2011 & 2012 & 2013 & 2014 & 2015 & 2016 & 2017 & 2018 & \\
\hline January & 315.0 & 48.5 & 213 & 93.5 & 138.4 & 505.4 & 201.6 & 116.8 & 202.8 & 103.2 & 126.8 & 386.7 & 204.3 \\
\hline February & 87.5 & 66.2 & 82.5 & 24.9 & 94 & 218.5 & 359.3 & 138.1 & 37.1 & 57.6 & 61.3 & 25.9 & 104.4 \\
\hline April & 232.4 & 130.0 & 56.2 & 44.7 & 83.3 & 64.3 & 199.8 & 104.2 & 62.5 & 81.9 & 192.0 & 97.6 & 112.4 \\
\hline May & 232.5 & 155.0 & 98.5 & 78.3 & 171.1 & 190.5 & 196.9 & 176.8 & 90.2 & 208.3 & 441.1 & 130.1 & 180.8 \\
\hline June & 242.7 & 367.0 & 132.8 & 176.9 & 73.8 & 146.2 & 173.9 & 196.8 & 75.2 & 95.6 & 272.6 & 132.6 & 173.8 \\
\hline September & 360.3 & 180.2 & 83.7 & 288 & 210.5 & 71.8 & 215 & 209.5 & 118.2 & 419.6 & 281.4 & 246.0 & 223.7 \\
\hline October & 353.8 & 170.0 & 175.1 & 255.2 & 206.2 & 240.3 & 266.7 & 298.3 & 149.4 & 352.4 & 360.4 & 177.0 & 250.4 \\
\hline November & 153.0 & 250.0 & 381.8 & 337.2 & 466.3 & 230.2 & 207.9 & 344.0 & 463.6 & 371.1 & 416.9 & 297.0 & 326.6 \\
\hline December & 383.0 & 272.0 & 233.2 & 459.9 & 510.9 & 523.9 & 641.7 & 304.3 & 232.8 & 431.8 & 183.9 & 208.5 & 365.5 \\
\hline $\begin{array}{l}\text { Yearly } \\
\text { average }\end{array}$ & 243.2 & 176.4 & 150.0 & 199.7 & 202.5 & 225.4 & 260.6 & 196.7 & 1.1 & 190.9 & 7.7 & 185.3 & \\
\hline
\end{tabular}

Source: Meteorology Station Class III Ranai, 2019

\section{Dipole Mode}

The local climate is also influenced by Natuna's topography, especially with the Ranai mountain in Bunguran island. Ranai mountain contributes to the formation of cumulonimbus clouds resulting in high precipitation. This cloud is formed by the Dipole mode in the Indian Ocean. This mode is an anomaly of water temperature which contradicts the western tropical part of the Indian Ocean and the eastern or southeast Indian Ocean. Two types of Dipole modes:

a) Positive Dipole Mode. A condition where water temperature in the western tropical part of the Indian Ocean is higher than the eastern resulting in high precipitation in the African eastern shore and western Indian Ocean (Kane, 1997). Whereas, the eastern part has lower precipitation and cause dryness in the majority of the Indonesian shore including Natuna Islands.

b) Negative Dipole Mode. A condition where an anomaly of water temperature in the western Indian Ocean is lower than the eastern parts causing dryness in eastern African shores and western Indian Ocean (Mulyana, 2002). Whereas, the eastern Indian Ocean has higher precipitation in the majority of Indonesian shores including Natuna Islands.

Based on the description of the monsoon wind, cyclones, and local climate, it can be inferred that the weather condition in Natuna is ever-changing with sudden rain, storms, and high tides. This is caused by the topographical features of Natuna which consist of hilly lands and rocky mountains (Wibisono, 2014). According to BMKG Ranai and precipitation logs, it is observed that Natuna Island has high rain intensity. The continuous rain is considered orographic rain as it is formed by ocean water evaporation. This causes warmer air in the seas as it contains steam moving up to the mountains and hills resulting in cold air. The evaporated water in the peak of the mountain and hill will condense and form water buds and turn to rain that falls on to the slopes. The dry air then flows to the other side of the mountain and forms an area of a rain shadow. The numerous hills and mountains in Natuna Island surrounded by waters form orographic rains to form and cause unpredictable weather. Moreover, according to precipitation logs from Meteorology Station Class III Ranai (Stasiun Meteorologi Kelas III Ranai), monthly rain in Natuna is between $105-$ $365 \mathrm{~mm}$ for a period of 12 years (2007-2018) (Table 2).

However, from annual observation, the precipitation rate is between $150-267 \mathrm{~mm}$. This is in line with the climate classification based on Oldeman-climate that in Natuna is categorized as humid and wet both monthly and yearly (Wahid \& Usman, 2017). Detailed precipitation in Natuna can be seen in Table 2.

Based on the wind data from Meteorology Station Class III Ranai, the monthly wind speed (the year 2007 - 2018) in Natuna was between $3-7$ knots or $6-13 \mathrm{~km} /$ hour (Figure 3 ). The highest wind speed was in January and February, which aligns with the effects of regional climate in Natuna that caused by the Asian Monsoon or the northern season. The information also aligns with the result of in-depth interviews with the fishers who stated that in these months, the sea waves in Natuna can reach up to 3 meters that make fishers unable to do fishing activities. According to the Beaufort scale, monthly wind speed in Natuna (3-7 knot) is enough to continuously move leaves and small branches and cause big waves (Stewart, 2008).

\subsection{Effects of Climate Change on Ecology}

One phenomenon of the global climate in Natuna is El Niño, where sea temperature 
changes in a particular time period. The increase of $1-2^{\circ} \mathrm{C}$ or higher for about $4-8$ weeks leads to Coral Bleaching Event (CBE) (Wouthuyzen et al. 2018). CBE is a condition where microscopic algae called zooxanthellae which symbiotic with the reefs, are peeled off and turn white as it loses the ability to survive. In Indonesian waters, CBE occurred in the year of 1982/83, 1996/97, 2010 and 2016. CBE in 2016 had a higher magnitude compared to 2010 and reached its peak in May until June (Wouthuyzen et al. 2018). This can be seen in Figure 4 where the white circles indicated CBE in Indonesia and blue circles indicate locations without CBE. The level of bleaching is at an Alert-1 and Alert-2 that covering $31.3 \%$ of Indonesian waters in 2010 and 39.4\% in 2016. This phenomenon occurred in Natuna and several reef locations in Indonesia.

The effects of climate change occur in three aspects: physics, ecology, and economy. Physical and ecological effects can be seen from changes in research locations and from the information gathered from the fishers. Climate change highly influences the physiology and behaviors of individuals, populations, and communities (Roessig et al., 2004) Extreme conditions such as higher temperatures, low concentration of dissolved oxygen, and water $\mathrm{pH}$ can cause death fishes. A less-thanoptimum environment can decrease metabolism, growth, and breeding capability of fish, as well as influence their space, metamorphosis, and endocrine system (Roessig et al., 2004).

All the changes directly affect the reef ecosystem, population, and structure of the fish community leading to a decrease in fish supply. Several effects of climate change on fish have been detected on mackerel (Trachurus trachurus), and anchovy (Famili Engraulidae).
Mackerel production increased between 19461987 as the concentration of phytoplankton and zooplankton increased. This anomaly also influences the tropical levels of the seas, the hydrographical, and atmospheric conditions on a 1-year scale. As a result, mackerels migrated and a decrease in population. However, several weeks after, El Nino brought in a mass of hot water halting the process of upwelling and decreasing anchovy production. This event indicated that ecological conditions also play a role (Stenseth et al., 2004; Reid et al., 2001). El Nino also affecs the production of skipjack fish. Nearly $70 \%$ of skipjack production in the world comes from the Pacific Ocean. They mostly live in the warm water of the west Pacific equator. However, as El Nino causes the movement of the warm waters, the spread of skipjack has also changed. Bleaching is a common phenomenon that occurs on the reef; however, mass bleaching is an uncommon symptom, which is usually triggered by a sudden change to higher water temperature (Marshall \& Baird, 2000.

This study revealed the community perception of five Natuna sub-regions whose reported that the reef damage is occurred less than $70 \%$. However, most people are not aware with the caused the damage, whether it is climate change of human behaviour who exploited the reef source using non environmental-friendly tools. Reef damages threaten to break the food chain in the sea ecosystem. It is concerning that the reef takes a long period of time to recover once it dies especially considering that $15 \%$ of reef in the world is located in Indonesia; $58 \%$ of tuna comes from the Pacific Ocean and tuna from Natuna is considered to be one of the best in the world. This condition can decrease the population from every part of the food chain

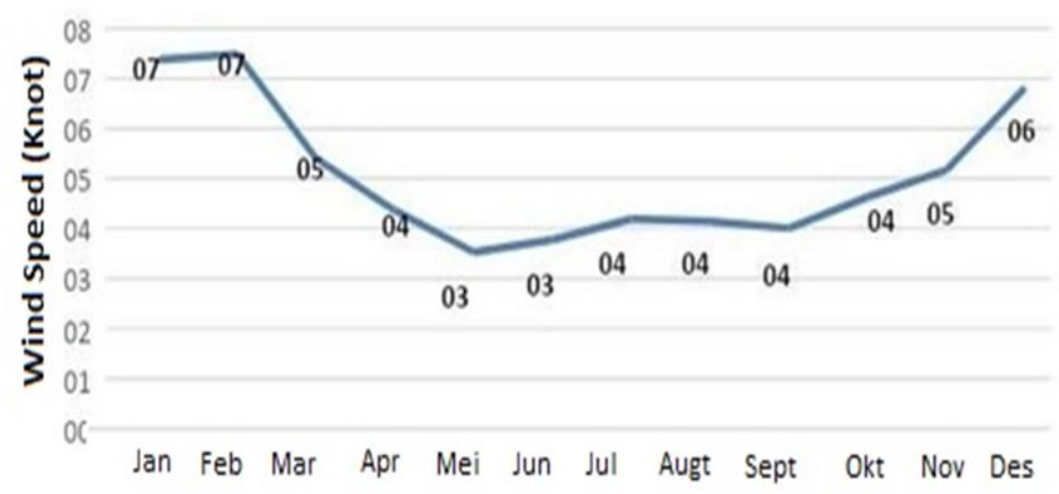

Figure 3. Average monthly wind speed between 2007 -2018 (Source: Meteorological, Climatological, and Geophysical Agency $3^{\text {rd }}$ Grade, Ranai) 
such as phytoplankton, zooplankton, small and big sea animals, predators, and decomposers (Umiati, 2012).

Aligned with a study done by (Rudi, 2012), there are 13 reef spesies that affected by bleaching in south Natuna i.e., Acropora, Montipora sp, Pocillopora sp, Stylophora sp, Seriatopora $s p$, Porites $s p$, Goniastrea $s p$, Platygyra sp, Diploastrea sp, Galaxea $s p$, Lobophylliam sp, Fungia sp, and Echinopora sp. This shows that even reef in good condition such as Porites as well as those in medium and low vulnerability status can be affected by bleaching.

\subsection{Extreme Climate Effects on Fishing} activities in Natuna

Climate change effects have been seen in the fishing and marine sectors. Fishers are vulnerable to climate change and its variability as they depend on the sea for a living. However, climate and weather also play a role in accessing the sea. The deteriorating environment due to climate change also strains the social and economic structures of the community (Adger et al., 2002). The waves in Riau, especially in the Natuna and Anambas waters depend on the seasonal wind patterns. During the transition season (SON), the average tides are higher than in the Asian and Australian monsoons (DJF and JJA). In the transition season (SON), the average tide reaches its peak in October with height up to 5 meters. However, in the Asian monsoon season, the highest wave was occurred in December with up to 3.5 meters; and in the Australian monsoon, the peak was occurred in July with height up to 2.5 meters.

According to Natuna fishers in last two years, storm season was occurred in January, February, and March. Despite the rain and storm in these months, fishers still conduct fishing activities as the tide's height were still below 3 meters, which is in contrast to five or ten years ago. Five years ago, storm seasons occurred in October, November, December, and January peaking in November. This also occured 10 years ago with its peak in December.

The concept of resilience can be used to understand the steps to protect the fishers' livelihood from the effects of damaging climate change. One aspect of resilience is patterns of adaptation in overcoming the changes

\section{Adaptation of fishers working patterns}

Fishers have typically specific characteristics in each region. In Natuna, fishers prefer fishing individually rather than in groups, with no more than 3 people, even though the
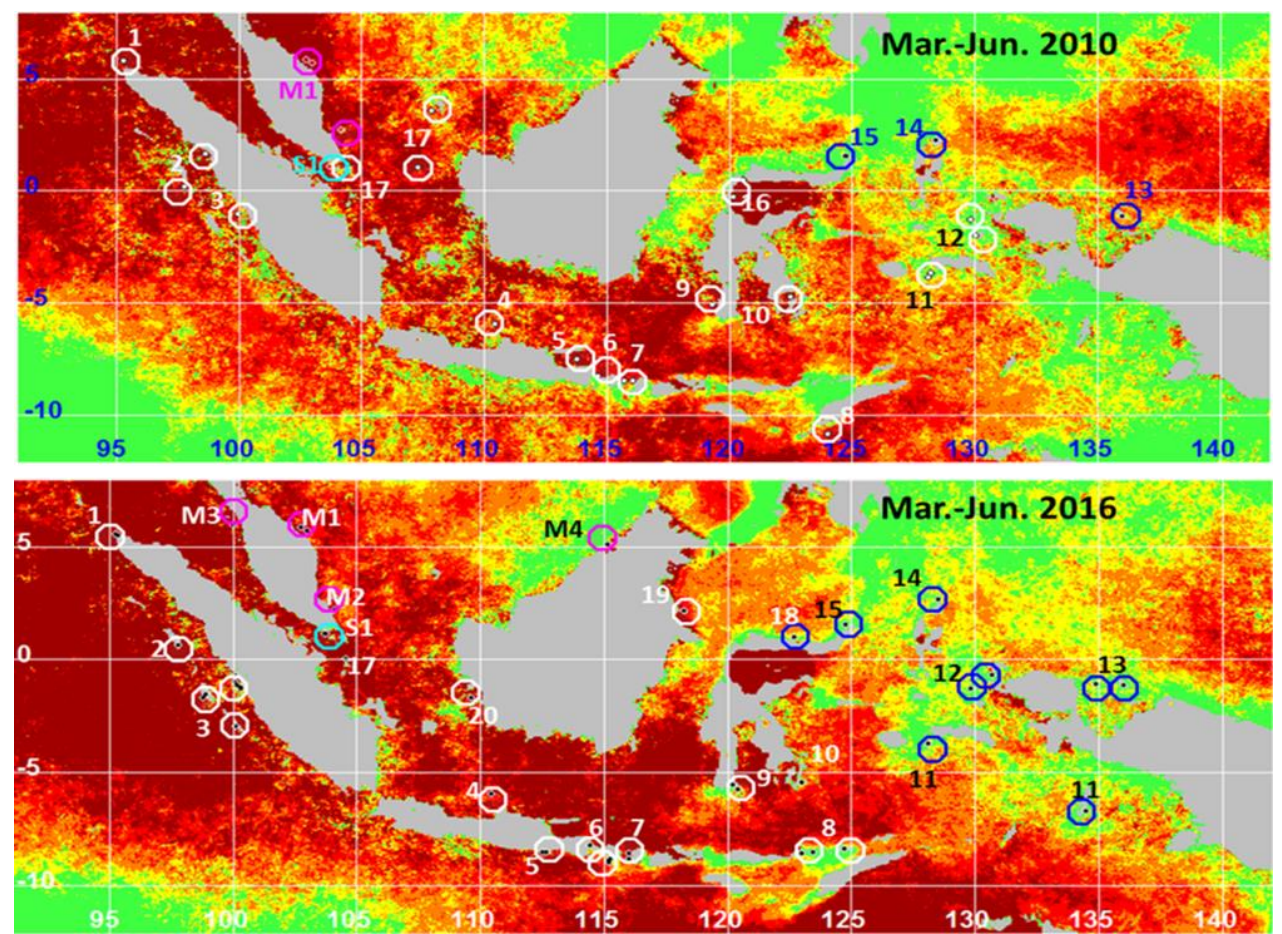

Figure 4. Coral Bleaching Event locations in 2010 (top) and 2016 (down) (Wouthuyzen et al., 2018) 


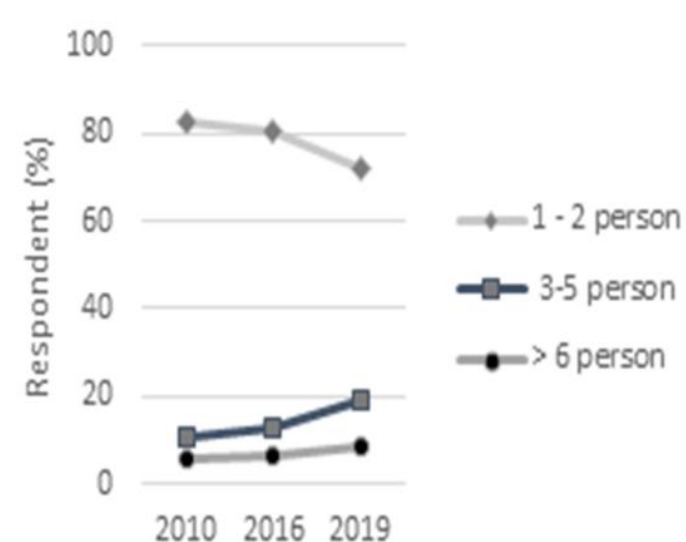

Figure 5. Change in group member

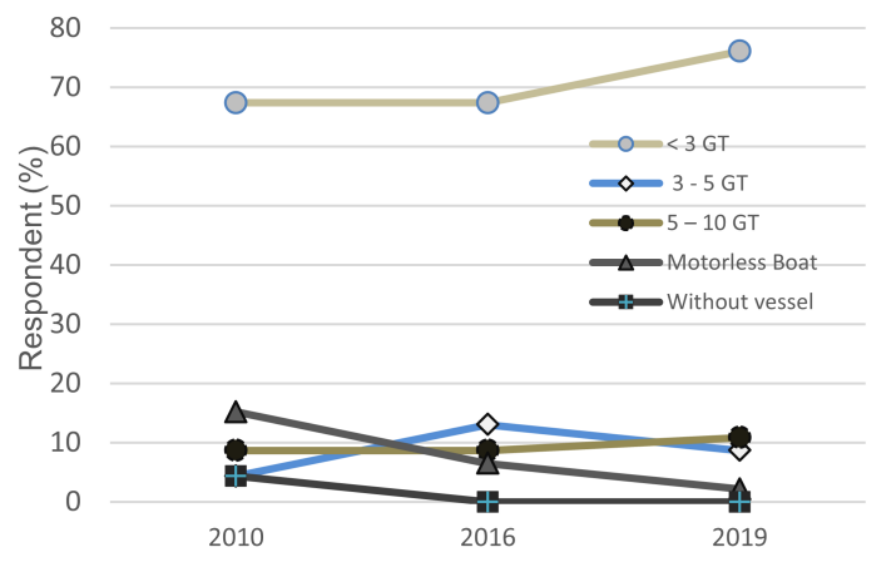

Figure 6. Change in vessel ownership in 2010, 2016, and 2019 ocean characteristic in Natuna is quite dynamic. In 2010, 38 respondents ( $83 \%$ ) said they prefer to work alone or in pairs. In 2016, 37 people $(80 \%)$ worked alone or in pairs, and in 2019 , $72 \%$ or 33 people respondents continued to work alone or in pairs. In the category of 3-5 members group, there were only 5 respondents (10\%). This number increased in 2010 to 7 people (13\%) and 9 respondents (19\%) in 2019, though the group has no more than 3 people. In the category of groups with $>6$ people, there were 3 respondents (7\%) in 2010 and 2016 . The number increased in 2019 to 4 respondents (9\%). Natuna fishers preferred to work alone and in pairs as they do not see a difference in the results of fishing. If there are more fishers in the vessel, they would have to equally divide the fishing results, which may be less than when working alone. However, there has been an increase in group fishing. In 2016, there was 1 respondent in the Northeast of Bunguran who added fishers to 3 people per vessel. In 2019, 4 respondents increased the fishers to 3-4 people per vessel. In the category of 3-4 member groups, 5 respondents (11\%) had 305 people per group in 2010. This number increased to 6 respondents (13\%) and 9 respondents (19\%) in 2019. This increase correlates with the size of the vessels. Figure 5 shows the change in group work in 2010, 2016, and 2019.

\section{Adaptation on fishing vessels}

The types of vessels used by Natuna fishers are dominated by vessels sized $<3$ GT in 2010, 2016 until 2019. In 2010, 68\% of respondents reported to have vessels sized $<3$ GT, $15 \%$ had motorless boats. No respondents had big vessels or with size >10 GT. The biggest vessel owned by a respondent is $5-10$ GT ( $9 \%$ of the respondent). This aligns with the number of people in the vessel which is between 1-2 persons. However, vessels with $<3$ GT had a significant change compared to other types of vessels. In contrast, those who only have motorless boats and those without vessels did not have experience any change. This

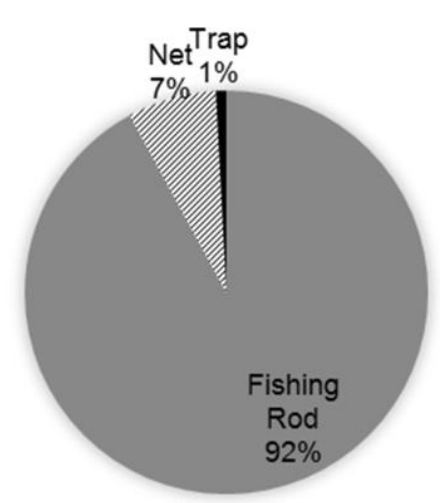

(a) 2010

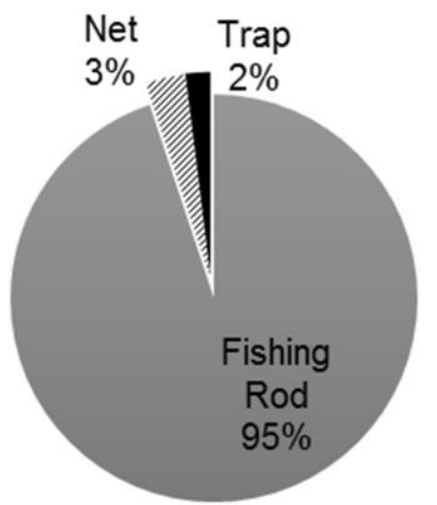

(b) 2016

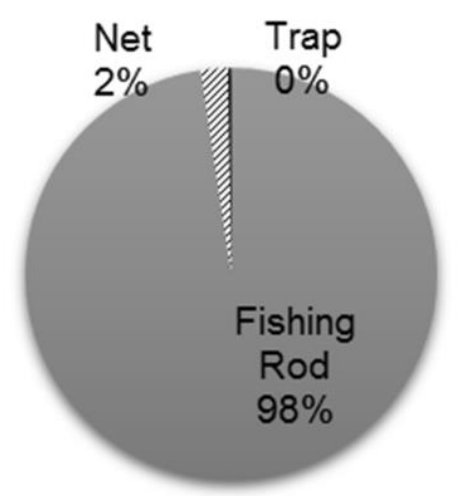

(c) 2019

Figure 7. Change in composition of fishing gears used by respondents in Natuna in 2010, 2016, and 2019 


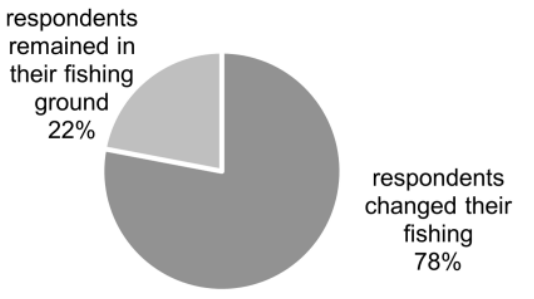

Figure 8. Respondents who changed fishing ground to adapt to climate change

shows that fishers adapted by changing their vessels which indicates their resilience against climate change. Data on vessel ownership is seen in the following Figure 6.

\section{Adaptation on Fishing Gears Composition}

The fishing gears are dominated by fishing rods. Based on data from Marine and Fisheries Agency of Natuna Regency in 2018, pancing ulur compiled $45 \%$ of all the fishing tools. The second highest is Pancing tonda at $31 \%$ followed by the rest of the gears.

Based on interviews, fishing gear used by respondents are mostly fishing rods. In 2010, $92 \%$ were rods, $7 \%$ were nets, and $1 \%$ were traps. In 2016 , $95 \%$ was rods, $3 \%$ nets, $2 \%$ was traps. This is like 2019 , where $98 \%$ were rods and $2 \%$ were nets, and no traps were used. This change is seen as a way of fishers to adapt to the weather in Natuna waters. In general, fishers in Natuna used several fishing gears for efficiency. However, there are fishers who used different fishing tools at different times depending on the conditions. In the windy season the fishers use nets when fishing is not possible, the fishers would use nets. According to fishers in Teluk Buton, they need to have a wider range of fishing gears to accommodate the weather conditions. One way to adapt with bad condition is to have various fishing gears as well as other sources of livelihood (informal labor or farming). The composition of fishing gears can be seen in Figure 7.

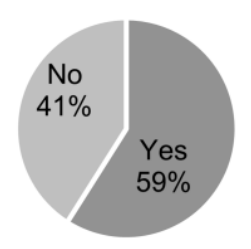

Figure 9. Respondents' Perception of Reef Damage/Burns due to climate change

\section{Adaptation on fishing ground locations}

As previously mentioned, climate change and extreme weather in Natuna affected the waters and environment in the South China Sea, one of which is coral bleaching. The damage reef drive fishers to find new fishing ground. Based on interviews, $78 \%$ of respondents changed their fishing ground and $22 \%$ remained in their fishing ground (as seen in Figure 8).

The cause of the change is due to a decrease in fish productivity in the original fishing grounds. According to the fishers, the decrease is caused by reef damage and the increase of fishing gears and vessels. The interviews revealed $56,52 \%$ of respondents had reported reef damage in their fishing areas. Figure 9 shows the respondents' perception of climate change.

Data from Marine and Fisheries Agency of Natuna Regency revealed that from 2011 to 2018, there was an increase in the number of vessels and fishing gears in Natuna. This also shows the increasing competition between fishers. To overcome these situations, the fishers added or changed their fishing gears, used additional tools such as GPS and fishfinder, and changed the size of their vessel. The change in the composition of fishing tools and vessels has been previously mentioned.

According to Achson (1981), fishers are highly dependent on technology to support their fishing activity and additional survival tools (Imron, 2003). The interviews revealed not all respondents used GPS or fish finder. However,

Table 3. Respondents using GPS and Fish finder in Natuna

\begin{tabular}{lrrrrrrr}
\hline \multirow{2}{*}{ Sub-region } & Number & \multicolumn{3}{c}{ GPS users } & \multicolumn{3}{c}{ Fish finder users } \\
\cline { 3 - 9 } & of Resp. & 2010 & 2016 & 2019 & 2010 & 2016 & 2019 \\
\hline South Bunguran & 8 & 2 & 5 & 5 & 1 & 1 & 1 \\
East Bunguran & 18 & 11 & 13 & 15 & 10 & 12 & 14 \\
Northeast Bunguran & 16 & 7 & 6 & 12 & 3 & 3 & 6 \\
North Bunguran & 1 & 0 & 0 & 0 & 0 & 0 & 0 \\
Pulau Tiga & 3 & 0 & 0 & 0 & 0 & 0 & 0 \\
\hline Number of resp. (person) & 46 & 20 & 24 & 32 & 14 & 16 & 21 \\
Percentage (\%) & 100 & 43.5 & 52.2 & 69.6 & 30.4 & 34.8 & 45.6 \\
\hline
\end{tabular}

Source: primary data 
from 2010 to 2019, there was an increase in the use of these tools. In 2010, respondents who used GPS were $43,48 \%$. This number increased to $69,57 \%$ in 2019 . The number of fish finder users also increased from $30,43 \%$ in 2010 to $45,65 \%$ in 2019. This use of technology is caused by the decrease of fishing ground and to reach other locations and increase fishing results. Table 3 shows the number of respondents who used GPS and fish finder in 2010, 2016, in 2019.

\section{Adaptation on livelihood}

In overcoming climate and weather change, the fishers in Natuna attempted to stay as fishers. However, an alternative livelihood is hard labor in constructions, though this is not reliable work. From the interviews, it can be seen that only $6 \%$ of the respondents sold their fishing gears and changed their livelihood, whereas $94 \%$ of respondents stayed as fishers (Table 4). Based on in-depth interviews, there is no equivalent alternative livelihood as fishers since they do not have other skills nor the finance to start a new business.

Natuna also has potential for plantations, especially coconuts. However, the commodity has not been optimally explored. In fact, coconuts are often wasted. Field observation revealed some abandoned coconut plantations where coconuts were left to fall and rot. This is because coconuts are only priced at $\mathrm{Rp} 1000$ per three coconuts. However, this can serve as an alternative livelihood for fishers in Natuna.

Climate and weather dynamics in Natuna influence community in small islands. As fishers heavily rely on nature, they face high uncertainty in their livelihood (Wibowo \& Satria, 2015). This makes them an extremely vulnerable group in relation to climate change (Numberi, 2009). Climate change and extreme weather decrease the accessibility to fishery resources. Climate change in Natuna also causes damage to the reef ecosystem. Extreme weather limits access to fishery resources as well. These two factors are inevitable for fishers, and in the concept of resilience, these are considered as "disruptions". As mentioned, resilience is a condition where a system can

Table 4. Fishers' Adaptation to livelihood

\begin{tabular}{lrrr}
\hline \multirow{2}{*}{ Sub-region } & \multirow{2}{*}{$\begin{array}{c}\text { Respondent } \\
\text { s }\end{array}$} & \multicolumn{2}{c}{$\begin{array}{c}\text { Selling } \\
\text { fishing gears }\end{array}$} \\
\cline { 3 - 5 } & 8 & 2 & \multicolumn{2}{c}{$\mathbf{n}$} & $\%$ \\
\hline South Bunguran & 18 & 0 & 0 \\
East Bunguran & 16 & 1 & 2 \\
$\begin{array}{l}\text { Northeast } \\
\text { Bunguran }\end{array}$ & 1 & 0 & 0 \\
$\begin{array}{l}\text { North Bunguran } \\
\text { Pulau Tiga }\end{array}$ & 3 & 0 & 0 \\
\hline $\begin{array}{l}\text { Number } \\
\text { respondents } \\
\text { (person) }\end{array}$ & 46 & 3 & 6 \\
\hline
\end{tabular}

absorb or overcome the changes that disrupt the system (Holling \& Gunderson, 2002)

The changes described above are disruptions to the societal system; and responses toward these changes are considered as resilience. Several experts stated that resilience is the ability of the system to maintain function, structure, identity, and feedback by absorbing the disruption and reorganizing as efficiently as possible (Proag, 2014; Folke et al., 2010). Resilience can be said as the ability to recover. In waters, these disruptions interfere with the ecosystem's stability. Furthermore, in society, it affects the balance of socio-economy. It can be said that resilience is a generated balance on the ecosystem as well as society's socio-economy state (Perrings et al., 1995; Foley et al., 2005; Brand \& Jax, 2007).

\section{CONCLUSION}

Natuna islands are in the North Natuna Sea and affected by the global climate and its variation. The socio-economic dynamics as fishers' resilience towards extreme climate are done by adjusting the number of workers and workforce, adjusting the size of fishing boats/ships, adjusting the composition of fishing gears, and changing fishing grounds.

The Asian-Australian Monsoon seasons are variations in the climate which heavily affect fishing activities every year in Natuna. During the Asian monsoon season (DecemberFebruary every year), some fishers do not have fishing activities, while others go fishing around the Bunguran island with vessels sized $<5$ GT. From December to February, the fish population including Benthos and phytoplankton increased, which led to upwelling. Fishing activities in Natuna are onde day fishing during the Australian monsoon and transition season. Fishers capture fish with pancing ulur or bubu (trap). However, the amount of fish is not as much as the north season as there was no upwelling in Natuna waters. In the Australian monsoon season (June until August every year), wind speed decreases and flow from Australia to Natuna. This season is also referred

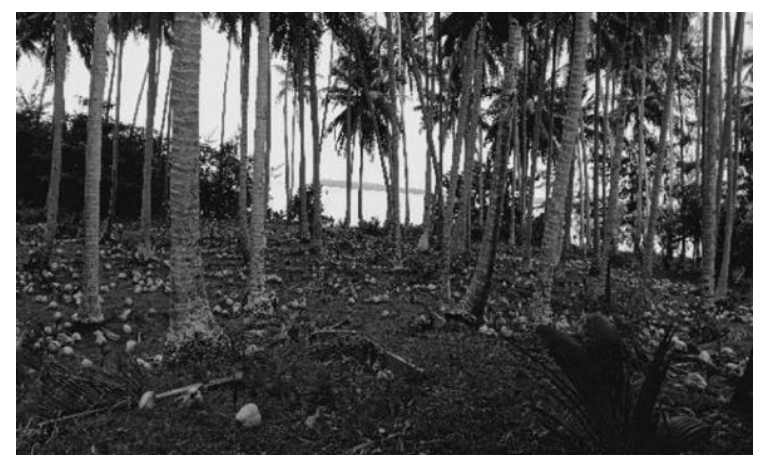

Figure 12. Abandoned coconut plantations 
to as a southern season. Moreover, March-May and September-November are transition seasons. In these seasons, storms often occur due to the difference in temperature and air pressure on the South China Sea waters and between the Philippines until Hongkong and Taiwan waters. However, due to the Coriolis movement, the effects of the storm are not significant in Natuna. The storm movement also forms cumulonimbus clouds that causing rain in Natuna waters. When this occurs, fishers operating in Natuna waters will take shelter in the bay or small islands surrounding the Bunguran Besar islands.

\section{Acknowledgments}

We acknowledge Marine and Fisheries Agency of Natuna Regency and Meteorology Station Class III Ranai for their support in this study, and Asri Nurul Qodri (Arizona State University) for their literary support.

\section{References}

Adger, W. N., Kelly, P. M., Winkels, A., Huy, L. Q., Locke, C. 2002. Migration, Remittances, Livelihood Trajectories, and Social Resilience AMBIO: A Journal of the Human Environment 31: 358-366

Aldrian, E., Karmini, M., Budiman. 2011. Adaptasi dan Mitigasi Perubahan Iklim di Indonesia. Pusat Perubahan Iklim dan Kualitas Udara, Badan Meteorologi, Klimatologi dan Geofisika

Bardhan, P. 1989. Alternative approach to the theory of institution in economic development. In P. Bardhan (eds). The Economic Theory of Agrarian Institutions Clarendon Press Oxford.

Bayong, T. H. K., Lubis, A., Juaeni, Ruminta, and Harijono, S. B. 2008. Impact of Variations in Pacific Ocean and Equatorial Indian Ocean Temperature on Rainfall in Indonesia. Aerospace Science Journal 5: 83-95.

Brand, F. S. and Jax, K. 2007. Focusing the Meaning(s) of Resilience: Resilience as a Descriptive Concept and a Boundary Object. Ecology and Society 12(1): 23.

Challen, R. 2000. Institution transaction cost and environment policy: Institution reform for water resources Edward Elgar Aldeshot (UK) and Vermont (USA).

Cheung, W. W. L., Lam, V. W. Y., and Sarmiento, J. L. 2009. Projecting global marine biodiversity impacts under climate change scenarios. Fish and Fisheries 10: 235-251.

Foley, J. A., DeFries, R., Asner, G. P., Barford, C., Bonan, G., Carpenter, S. R., Chapin, F. S., Coe, N. T., Daily, G. C., Gibbs, H. K., Helkowski, J. H., Holloway, T., Howard, E. A., Kucharik, C. J., Monfreda, C., Patz, J. A., Prentice, J. C., Ramankutty, N., and Snyder, P. K. 2005. Global consequences of land use. Science 309: 570-574.

Folke, C., Carpenter, S. R., Walker, B., Scheffer, M., Chapin, T., and Rockstrom, J. 2010. Resilience Thinking: Integrating Resilience, Adaptability and Transformability. Ecology and Society 15: 20-29.

Hafsaridewi, R., Fahrudin, A., Sulistiono, Sutrisno, D., and Koeshendrajana, S. 2019 Resiliensi nelayan terhadap ketersediaan sumberdaya perikanan di Kepulauan Karimunjawa. Jurnal Pengelolaan Sumberdaya Alam dan Lingkungan 9: 527540.

Hardian, S. 2015. Sekilas Sistem Monsun AsiaAustralia. Intergovernmental Panel on Climate Change (IPCC) 5th Assessment Report, 2013.

Holling, C. S. 1973. Resilience and stability of ecological systems. Annual Review of Ecology and Systematics 4: 1-23.

Holling. C. S., and Gunderson, L. H. 2002. Resilience and Adaptive Cycles. In: L.H. Gunderson \& C.S. Holling (eds.). Panarchy; understanding transformations in human and natural systems. Washington, DC: Island Press

Imron, M. 2003. Kemiskinan Dalam Masyarakat Nelayan. Jurnal Masyarakat dan Budaya 5: 61-82.

Kane, R. P. 1997. Relationship of El NinoSouthern Oscillation and Pacific Sea Surface Temperature with Rainfall in Various Region of the Globe. Monthly Weather Review 125: 1792-1800.

Manyena, S. B. 2006. The concept of resilience revisited. Disasters 30: 433-450.

Marshall, P. A. and Baird, A. H. 2000. Bleaching of coral on the Great Barrier Reef: differential susceptibilities among taxa. Coral Reef 19: 155-163.

Mulyana, E. 2002. Pengaruh Dipole Mode Terhadap Curah Hujan di Indonesia. Jurnal Sains \& Teknologi Modifikasi Cuaca 3: 3943 
Nazir, M. 2003. Metode Penelitian. Jakarta: Salemba Empat.

North, D. C. 1990. Institution, Institutional change and economic performance and economic performance Cambridge Univ. Press. Cambridge.

Numberi, F. 2009. Perubahan Iklim: Implikasi terhadap Kehidupan di Laut, Pesisir dan Pulau-pulau Kecil. Jakarta: Citrakreasi Indonesia

Perrings, C. A., Mäler, K. G., Folke, C., Holling, C. S., and Jansson, B. O. editors. (1995). Biodiversity Conservation and Economic Development: The Policy Problem Biodiversity Conservation Spriner Dordrecht

Proag, V. 2014. Assessing and Measuring Resilience. 4th International Conference on Building Resilience 2014: 8-11.

Rahayu, D. N., Sasmito, B., and Bashit, N. 2018. Analisis Pengaruh fenomena Indian Ocean Dipole (IOD)Terhadap Curah Hujan di Pulau Jawa. Jurnal Goedesi Undip 7: 57-67.

Reid, P. C., Holliday, N. P., and Smyth, T. J. 2001 Pulses in the Eastern Margin Current and Warmer Water off the North West European Shelf Linked to North Sea Ecosystem Changes Marine Ecology Progress Series 21523887

Roessig, J. M, Woodley, C. M., Cech, J. J., and Hansen, L. J. 2004. Effects of global climate change on marine and estuarine fishes and fisheries. Reviews in Fish Biology and Fisheries 14: 251-275.

Rudi, E. 2012. Pemutihan Karang di Perairan Laut Natuna Bagian Selatan tahun 2010. Jurnal Biospecies 5: 1-7.

Stenseth, N. C., Ottersen, G., Hurrel, J., and Belgrano, A., Eds. 2004 Ecological Effects of Climate Variations in the North Atlantic. Oxford University Press, 252 pp

Stewart, R. H. 2008. Introduction to Physical Oceanography. Texas: Department of Oceanography Texas A \& M University
Syaifullah, M. D. 2015. Siklon Tropis, Karakteristik Dan Pengaruhnya Di Wilayah Indonesia Pada Tahun 2012. Jurnal Sains dan Teknologi Modifikasi Cuaca 16: 61-71

Umiati, F. 2012, Pengelolaan Berkelanjutan Terhadap Terumbu Karang (Coral Reefs) di Laut Natuna, Kepulauan Riau. https://autumnsite.wordpress.com/2013/0 5/25/pengelolaan-berkelanjutan terhadapterumbu-karang-coral-reefs-di-lautnatuna-kepulauan-riau.

Wahid, H., and Usman. 2017. Analisis Karakteristik dan Klasifikasi Curah Hujan di Kabupaten Polewali Mandar Jurnal Sainsmat 6: 15-27.

Wheleer, M. C., Lau, W. K., and Mcbride, J. 2005. Australian-Indonesian Monsoon, In: Intraseasonal Variability in the Atmosphere-Ocean Climate System. Springer Praxis Books (Environmental Sciences). Springer, Berlin, Heidelberg.

Wibisono, S. C. 2014. Arkeologi Natuna: Koridor Maritim Di Perairan Laut Cina Selatan Kalpataru. Majalah Arkeologi 23: 81-150.

Wibowo, A., dan Satria, A. 2015. Strategi adaptasi nelayan di Pulau-pulau Kecil terhadap Dampak Perubahan IklimKasus: Desa Pulau Panjang, Kecamatan Subi, Kabupaten Natuna, Kepulauan. Riau Sodality: Jurnal Sosiologi Pedesaan 2015: 107-124.

Wouthuyzen, S., Abrar, M., and Lorwens, J. 2018. A Comparison Between the 2010 dan 2016 El-Nino induced coral bleaching in The Indonesia waters. IOP Conf. Series: Earth and Environmental Science 118: 1-15.

Yeager, T. J. 1999. Institution, Transition economies, and economic development. Political Economy of Global Interdependence. Oxford. 